\section{The Higher Education System in Israel}

\section{Nissan Limor}

Nissan Limor is director general of the Council for Higher Education of Israel. Address: POB 4037, Jerusalem 91040, Israel.

Some 50 years after the establishment of the state of Is$\checkmark$ rael and some 75 years after the opening of the first institutions for higher education in Israel, Israeli higher education is facing new challenges at the threshold of the 21 st century. The first two institutions emerged as part of the Jewish settlement in Israel in the early years of the century, especially with the waves of new immigrants that arrived after World War I. In 1948, at the time of the establishment of Israel, only about 1,500 students attended these two institutions. During the first decade of the state of Israel, two new universities were opened, and the number of students at the end of the 1950s reached about 9,500. During the 1960s, two more universities were opened, ${ }^{1}$ and the number of students at the end of this decade stood at 35,000 . In the 1970 s the number of students grew by some 55 percent, to about 55,000 , in 1979 . The 1990 s were years of very fast growth. The number of students doubled, reaching about 150,000 in 1998. Some 29 new institutions for higher education were opened. ${ }^{2}$

In an international comparison, Israel occupies a very respectable position: 10th place regarding the number of students per capita in postsecondary education, and 7th regarding the proportion of entering students in tertiary and higher education in an average cohort (after the United States, Japan, Denmark, Sweden, France, and Germany). Israel stands in third place (after Germany and the United Kingdom) in the number of degrees awarded in mathematics, computer sciences, the natural sciences, and engineering, as well as in the number of advanced degrees awarded relative to the size of the work force. These figures are the fruit of a clear policy and ongoing national investment in education at all levels and especially in higher education. The national expenditure on tertiary education in Israel is 1.7 percent of the GDP, which places Israel second (after the United States) in international comparisons with developed countries. Regarding the national expenditure per student in postsecondary education as a percentage of the GDP, Israel takes the first place (at 73.4 percent) among developed countries. ${ }^{3}$

The framework of the system of higher education in Israel is defined in the higher education law, enacted in 1958. This law established the Council for Higher Education and procedures for the accreditation of institutions of higher education, as well as the powers and responsibilities of the council. Its council acts as a buffer body between the government and academia. The principal functions are to accredit an institution as an institution of higher education; to grant a permit for an academic program; to authorize an accredited institution to confer an academic degree; to license the branches and extensions of foreign universities to operate in Israel; and to make recommendations to the government regarding higher education planning (including the establishment of additional institutions of higher education). The council has 24 members, appointed by the president of the country, chaired ex-officio by the minister of education. The vice-chairman of the council is traditionally a former justice of the Supreme Court.

The higher education law defines the unique status of the institutions of higher education. It states that institutions of higher education enjoy academic and administrative independence. In this sense, the Israeli law is unique: no similar law exists, in any other known country, that grants such a vast degree of academic and administrative freedom to institutions of higher education.

Up until the early 1970s, the council dealt only with academic issues, while the Ministry of Education treated budgetary issues. In 1972 the council decided to establish, as a permanent subcommittee, the planning and budgeting committee (PBC) and to delegate to it the planning and budgeting responsibilities of the council. This step was endorsed by a government decision defining the PBC's role as an independent intermediary body between the government and institutions of higher education in all matters relating to planning and allocations. The $\mathrm{PBC}$ examines requests to open new institutions, new units, or new academic programs-from the planning, budgetary and financial points of view - and submits its recommendations to the council. The council will not consider any request unless it has been discussed and recommended by the PBC.

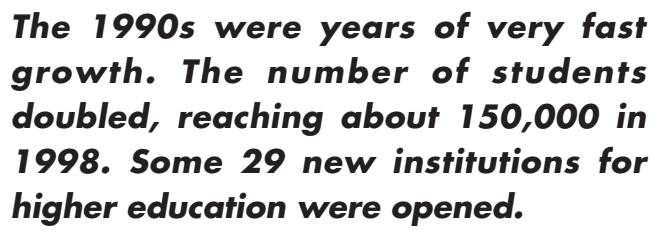

The PBC is composed of six members: four are distinguished professors from universities (one of whom is the chair) and the other two are public figures from the economic, business, or the industrial sectors of the country. The council and the PBC set four goals for higher education: creating new knowledge and maintaining excellence in research, conducting high-quality academic teaching, preparing future researchers and teachers, and supplying the economy with skilled academic manpower. It would 
seem that such goals would call for detailed planning, but the council and the PBC have refrained from getting involved in detailed planning and allocation. This policy reflects not only the unique legal independence of the institutions but also stems from a democratic and liberal orientation not to intervene with the individual's choice of what or where to study. The council and the PBC see it as their responsibility to make higher education accessible to any individual who is capable, ready, and desirous of acquiring higher learning.

\section{The higher education law defines the unique status of the institutions of higher education.}

The PBC's activities, therefore, are aimed at planning the optimal use of the national resources for higher education, rather than planning academic trends or activities. One of the council's activities is short- and mid-range forecasts (5 to 10 years). This requires constant hands-on attention to current trends in the society, the economy, and the labor market. The council intervenes in these processes only in exceptional cases-when an extreme trend is discerned or when the state has a special interest in encouraging a particular field of study. An example of the council's response to an extreme trend was the case of programs in law and business administration: while demand for access to programs in these two fields was huge, the PBC decided that the state should not subsidize this surge in demand and therefore limited the extent of its support. Instead, institutions that are not publicly funded (i.e., private institutions) were authorized to offer programs of study to anyone who wished to study these subjects, but at full cost and without any government subsidy. Another example of the council's response is the special allocations provided by the $\mathrm{PBC}$ in order to encourage institutions to increase the number of students in high-technology subjects. This policy was in direct response to the severe shortage of academically trained professionals in these fields. A further example of the PBC's method of operation is the development of a system of colleges in Israel, which is part and parcel of the PBC's conviction that the higher education system should be diversified. Thus, colleges have been established to provide high-quality academic instruction without the concomitant obligation to research that is inherent in the role of a university. The policy of diversification also led to the authorization of private (not publicly funded) colleges.

In determining the allocation of resources, the $\mathrm{PBC}$ employs various models for the objective evaluation of re- search and instruction output. It should be noted that allocation is according to output and not according to input. These models include performance indicators that measure actual performance and not just the efforts required to achieve it. This serves to reduce the dependence of institutions on the budgeting mechanism.

The implementation of such a policy necessitates, first and foremost, of a steady and efficient supply of data to provide the $\mathrm{PBC}$ with the tools to work effectively as well as keep abreast of changes in the "market" for higher education. The PBC, therefore, devotes a good deal of energy to the maintenance of an independent database, using statistics drawn from a variety of bodies (e.g., ministries, government agencies, the Central Bureau of Statistics, industry, etc.).

The achievements of the Israeli higher education system testify to the effectiveness of the Israeli model of a buffer body (the council and the PBC) between government and academia, which combines the functions of academic accreditation, planning, and the allocation of resources. The success of this system is even more conspicuous when considered quantitatively: when the PBC was established in the early 1970 s there were seven institutions with a total of only 35,000 students. Since then the number of students has increased fivefold and the number of institutions sevenfold. This rapid growth, accomplished while maintaining exemplary standards of academic excellence, could not have taken place without a central, supportive system. The success of the system derives not only from the efficiency of its operation but also from the legal reality in which the institutions of higher education operate and from the liberal-democratic traditions in Israel.

\section{The achievements of the Israeli higher education system testify to the effective- ness of the Israeli model of a buffer body.}

\section{Notes}

1. The Technion (Israel Institute of Technology) I Haifa and the Hebrew University of Jerusalem were founded in 1925; Bar-Ilan University in Ramat-Gan, in 1955 and Tel-Aviv University, in 1956; the University of Haifa, in 1963, and Ben-Gurion University of the Negev in Beer-Sheva, in 1964.

2. The figure 150,000 does not include some 30,000 students in the Open University (established in 1980); and the total number of institutions is 49 (8 universities, 22 colleges and academies, and 19 teacher training colleges).

3. These rankings are based on data provided by UNESCO, the OECD, and the Israeli Central Bureau of Statistics. 